\title{
Pulmonary valve agenesis-intact ventricular septum-persistent ductus arteriosus syndrome
}

INSERM

\section{Source}

INSERM. (1999). Orphanet: an online rare disease and orphan drug data base. Pulmonary valve agenesis-intact ventricular septum-persistent ductus arteriosus syndrome. ORPHA:99048

A rare, life-threatening, congenital, non-syndromic, conotruncal heart malformation disease characterized by absent or severely undeveloped pulmonary valve leaflets (with a restrictive ring of thickened tissue at the place of the pulmonary valve annulus), associated with an intact ventricular septum and a patent ductus arteriosus, manifesting with marked respiratory insufficiency. Additional features include dilated main pulmonary artery (with or without dilatation of pulmonary artery branches), to-and-fro flow at site of the dysplastic pulmonary valve, and systolic pressure gradient across narrowed pulmonary valve. Tricuspid atresia and variable extra-cardiac anomalies (e.g. diaphragmatic hernia or cleft lip/palate), may be present. 